Boston University School of Law

Scholarly Commons at Boston University School of Law

Faculty Scholarship

9-4-2009

\title{
Misguided Relief: The Real Property Tax Addition to the Standard Deduction
}

Alan L. Feld

BU Law

Follow this and additional works at: https://scholarship.law.bu.edu/faculty_scholarship

Part of the Taxation-Federal Commons, Taxation-State and Local Commons, and the Tax Law

Commons

\section{Recommended Citation}

Alan L. Feld, Misguided Relief: The Real Property Tax Addition to the Standard Deduction, in No. 09-42 Boston University School of Law Working Paper (2009).

Available at: https://scholarship.law.bu.edu/faculty_scholarship/653

This Article is brought to you for free and open access by Scholarly Commons at Boston University School of Law. It has been accepted for inclusion in Faculty Scholarship by an authorized administrator of Scholarly Commons at Boston University School of Law. For more information, please contact lawlessa@bu.edu. 


\title{
BU School of Law
}

\section{Misguided Relief: The ReAl Property TAX AdDITION TO THE STANDARD DEDUCTION}

\author{
Boston University School of Law Working Paper No. 09-42
}

(September 4, 2009)

Alan L. Feld

This paper can be downloaded without charge at:

http://www.bu.edu/law/faculty/scholarship/workingpapers/2009.html 


\title{
Misguided relief: the real property tax addition to the standard deduction.
}

\author{
Alan L. Feld ${ }^{*}$
}

The push to use federal money for benevolent purposes occasionally produces more cost than benefit, particularly when the outlay comes in the form of taxes forgiven. The Housing Assistance Tax Act of 2008 added a supplement to the basic standard deduction. ${ }^{1}$ A nonitemizing taxpayer may claim a deduction for real property taxes paid, up to $\$ 500, \$ 1,000$ in the case of a joint return. Initially, the change applied only to 2008 , but subsequent legislation extended its life through 2009, ${ }^{2}$ and pending legislation would make it a permanent part of the Code. ${ }^{3}$ Although well intentioned, the real property tax provision makes little sense as a matter of tax policy and Congress should allow it to expire as scheduled. Whether analyzed from the perspective of the standard deduction and its function within the Code or from that of the deduction for state and local taxes, the provision adds little utility but does contribute to complexity and incoherence.

\section{Background}

The standard deduction entered the Code during World War II when Congress “democratized" the income tax and changed its character from a tax on the well-to-do to a mass tax. ${ }^{4}$ To obviate the need to keep records of itemized deductions for millions of taxpayers and to eliminate the burden on the government of auditing the details of so many returns, Congress created the standard deduction in lieu of the itemized deductions. ${ }^{5}$ The amount of the standard deduction generally exceeds the total of the itemized deductions it replaces, often by a substantial amount. ${ }^{6}$ The level of the standard

\footnotetext{
* Professor of Law and Maurice Poch Faculty Research Scholar, Boston University School of Law.

${ }^{1}$ P.L. 110-289, section 3012(b), 122 Stat. 2654, 2877 (2008), codified at Code section 63(c) (1)(C) and 63(c)(7).

2 Tax Extenders and Alternative Minimum Tax Relief Act of 2008, P.L. 110-343, Division C, section 204, 122 Stat. 3861, 3865 (2008).

${ }^{3}$ H.R. 2604, $111^{\text {th }}$ Cong., $1^{\text {st }}$ Sess., introduced May 21, 2009.

${ }^{4}$ Individual Income Tax Act of 1944, 58 Stat. 231, 236 (1944).

590 Cong. Rec. 4011 (1944) (statement of Rep. Cooper).

${ }^{6}$ The standard deduction initially consisted of $10 \%$ of AGI up to $\$ 500$. The Treasury estimated that itemized deductions amounted to $8 \%$ on average and deliberately set the
} 
deduction thus balances a tradeoff between simplification and accurate income measurement. ${ }^{7}$ A taxpayer who claims the standard deduction cannot also claim deductions for medical expenses, charitable contributions, expenses to produce nonbusiness income, or state and local taxes. ${ }^{8}$ Congress has altered the form of the standard deduction several times, but in recent decades the deduction has consisted of a fixed dollar amount (adjusted for inflation) with only two modifications, for age and blindness. ${ }^{9}$ In the wake of Hurricane Katrina and certain other natural disasters, Congress in 2008 allowed standard deduction claimers to deduct specified disaster losses. At the same time, it added the real property tax adjustment "to help lessen the impact" of rising real property taxes even for individuals who did not itemize their deductions. ${ }^{10}$ The Ways and Means Committee estimated the revenue loss of the real property tax adjustment for a single year at $\$ 1.2$ billion. ${ }^{11}$

\section{Effects of the additional deduction}

About two-thirds of all individual income tax returns claim the standard deduction, predominantly from taxpayers with lower adjusted gross incomes. ${ }^{12}$ The standard deduction continues to offer them relative simplicity - no need to calculate the amounts expended for itemized deductions or to keep the necessary records. It also spares the IRS the need to audit relatively small amounts on numerous returns. The newest additions for disaster loss and real property tax, however, do require recordkeeping. Moreover, many nonitemizers can file on Form 1040-EZ, a return with only a few lines to fill. Over 23 million taxpayers did so in $2007 .{ }^{13}$ The simplicity of Form 1040-EZ depends on use of an unadjusted number for the standard deduction. Accordingly, taxpayers who claim any of the enhancements to the standard deduction --

percentage for the standard deduction at the higher level. 90 Cong. Rec. 4024 (1944) (statement of Rep. Knutson).

${ }^{7}$ See Louis Kaplow, The Standard Deduction and Floors in the Income Tax, 50 Tax L. Rev. 1 (1994).

${ }^{8}$ Code section 63(e).

${ }^{9}$ Code section 63(c)(3) and (f). A taxpayer may claim an additional deduction if over age 65 or blind.

${ }^{10}$ House Ways and Means Committee, H.R. Rep. 110-606 at 42 (2008).

${ }^{11}$ Id. at 74.

${ }^{12}$ Internal Revenue Service, Statistics of Income, Spring 2009, Table 1, at 118.

${ }^{13}$ Id. at 116. 
the adjustments for age, blindness and disaster losses -- cannot use this simple form and must file using the longer forms. ${ }^{14}$ The new real property tax deduction will further diminish Form 1040-EZ use by a significant number, since eligibility to claim the new deduction may be widespread. These taxpayers and the IRS will lose the simplification benefits of the 1040-EZ form.

The standard deduction also serves a second function. Together with the personal exemption it removes from an individual's tax base an amount roughly keyed to the poverty level. For 2009 the amount of the combined personal exemption and basic standard deduction for a married couple filing jointly is $\$ 18,700 .{ }^{15}$ Significantly, the benefit of any increase in the amount of the standard deduction can accrue only to taxpayers whose income exceeds this level. ${ }^{16}$ Thus, a married couple with income of $\$ 16,000$ would see no benefit from the added deduction for real property taxes, since their taxable income without the real property tax deduction in any event would stand at zero and the added deduction would make no change. A married couple with twice or three times that income, on the other hand, would benefit from the increase in the standard deduction. At the maximum deduction of $\$ 1,000$ their tax saving would amount to $\$ 100$ or $\$ 150 .{ }^{17}$

Congress generally has withstood "double dip" efforts to add any of the itemized deductions to the standard deduction. Each of the itemized deductions has its own appealing rationale and occasionally legislators have been tempted to make one or more of these deductions available to nonitemizers. For a short period, nonitemizers could deduct a portion of their charitable contribution deductions. ${ }^{18}$ Supporters of that

\footnotetext{
${ }^{14}$ Form 1040-EZ Instructions, at 5-6 (2008).

${ }^{15}$ Rev. Proc. 2008-66, IRB 2008-45, 1107. If the couple claims additional personal exemptions for dependent children, the amount of the combined personal exemption and standard deduction increases.

${ }^{16}$ The income level at which an increase in the standard deduction can provide any benefit will rise further to the extent that the taxpayer enjoys any nonrefundable credits such as the credit for dependent care, section 21.

${ }^{17}$ The marginal tax rate for joint return filers for 2009 is $10 \%$ up to taxable income of $\$ 16,700$ and $15 \%$ between $\$ 16,700$ and $\$ 67,900$. A small percentage of standard deduction filers will have taxable incomes that exceed $\$ 67,900$ and their marginal tax rate is $25 \%$.

${ }^{18}$ For 1982 and 1983 nonitemizers could deduct a maximum of $\$ 100$ and for 1984, $\$ 300$.
} 
provision argued that the presumed incentive effects of the charitable contribution deduction should extend to nonitemizers. ${ }^{19}$ A charitable contribution deduction, they asserted, would encourage taxpayers, even of modest means, to contribute more to charity than otherwise, by reducing the net cost of the gift to the donor.

In contrast, a modest reduction in the cost of the liability for real estate taxes seems unlikely to have any incentive effect on a nonitemizing taxpayer. At a marginal $10 \%$ or $15 \%$ rate, the extra $\$ 1,000$ deduction would reduce the cost of the taxpayer's monthly housing bill by a maximum of $\$ 12.50$, not an amount likely to move someone to purchase a home or to prevent foreclosure of one. On the other hand, it could create some small incentive to local taxing authorities to increase rates in order to soak up the federal benefit.

The added deduction also raises serious questions of equity. It extends to lower income families the Code's long-standing discrimination in favor of homeowners and against renters. ${ }^{20}$ Tenants bear their proportionate share of the real estate tax burden through the rent they pay to landlords, but receive no deduction. The new supplement to the standard deduction continues that practice. It also discriminates against residents of states that fund local services out of income or sales taxes in order to keep real estate taxes low. ${ }^{21}$

\section{The real estate tax deduction}

From the perspective of the real property tax deduction, the new provision bears no coherent rationale. Tax theorists have disagreed about the desirability of the state and local tax deduction. Its proponents argue that it provides a federal subsidy to enable state and local governments to provide needed services. ${ }^{22}$ Some would argue that any

\footnotetext{
${ }^{19}$ Staff of the Joint Committee on Taxation, $97^{\text {th }}$ Cong. $1^{\text {st }}$ Sess., General Explanation of the Economic Recovery Tax Act of 1981, at 49.

${ }^{20}$ See Rev. Rul. 79-180, 1979-1 CB 95. For a recent commentary, see Kenya Covington and Rodney Harrell, From Renting to Ownership: Using Tax Incentives to Encourage Homeownership Among Renters, 44 Harv. J. on Legis 97, 107 (2007).

${ }^{21}$ Representative Paul Hodes, the sponsor of the legislation, represents the second district of New Hampshire, a state that has no income or sales tax, but high real estate taxes.

${ }^{22}$ See Brookes D. Billman and Noel B. Cunningham, Jr., Nonbusiness State and Local Taxes: The Case for Deductibility, 28 Tax Notes 1107, 1108 (1985)
} 
involuntary levy at the state and local level reduces an individual's "ability to pay" federal tax and constitutes a proper reduction in calculating taxable income. ${ }^{23}$ Critics regard real property taxes as analogous to payments for personal consumption: the tax "buys" a set of services from the local government that benefit individuals in much the same way as other personal consumption expenditures. ${ }^{24}$ Perhaps that view supports the disallowance of any deduction for state and local taxes for alternative minimum tax purposes. ${ }^{25}$ But whether taken singly or collectively, these arguments would not give rise to a tax pattern giving full deduction to middle-income itemizers, denying deduction to higher income individuals subject to the alternative minimum tax and allowing a partial deduction to individuals who take the standard deduction.

Moreover, as a recent GAO report found, itemizers suffer confusion as to what qualifies as the proper amount to deduct as real property taxes. ${ }^{26}$ The Internal Revenue Service appears to have a similar difficulty. Levies for services such as water or trash collection fall outside the definition of deductible real property taxes, but many taxpayers nonetheless claim them as deductions. Tax bills from local government authorities often do not distinguish federally deductible items from those not deductible. The real property tax addition undoubtedly extends this confusion and misreporting to standard deduction filers.

\section{Conclusion}

In sum, the real property tax addition to the standard deduction gives a relatively small tax reduction to many nonitemizing taxpayers, but only if their income lies above the poverty level, they own their own homes and their local governments levy substantial real estate taxes. The provision gives no tax benefit to renters and to the lowest income taxpayers. It confers its benefits at the cost of simplification, including reduced use of the Form 1040-EZ. The budgetary cost consists of between one and two billion dollars annually in revenue. The deduction will have no discernable impact on the housing

${ }^{23}$ See generally Edward A. Zelinsky, The Deductibility of State and Local Taxes: Income Measurement, Tax Expenditures and Partial, Functional Deductibility, 6 Am. J. of Tax Pol'y 9 (1987).

${ }^{24}$ Senate Finance Committee, S. Rep. 99-313, 56 (1985) (reprinted in 1986-3 CB 3).

${ }^{25}$ Code section 56(b)(1)(A)(ii).

${ }^{26}$ US Govt. Accountability Office, Report to the Joint Committee on Taxation, Real Estate Tax Deduction (May 2009). 
market by way of preventing foreclosure or encouraging new purchases. Since repeal seems politically improbable, as the next best solution Congress should do nothing and allow the provision to disappear as scheduled after 2009.

(see HR 2725, seeking to extend for five years) 